\title{
VIGASZÁG VAGY KIRÁLYI ÚT
}

\author{
POLÓNYI ISTVÁN \\ Debreceni Egyetem, Bölcsészettudományi Kar, \\ Nevelés- és Müvelődéstudományi Intézet
}

A tanulmány a felsőoktatási felnőttképzéssel foglalkozik, amely jelentős változáson ment keresztül a 20. század végétől: a korábbi kompenzáló, pótló szerep helyett a továbbképző, átképző szerepe kerül előtérbe.

A tanulmány először áttekinti a magyar felsőoktatás elmúlt negyed századának hallgatólétszám-alakulását, és az elmúlt időszak felvételi tendenciáit, vizsgálva a felvett hallgatók korstruktúráját, a részidős hallgatók és a már diplomával rendelkezők arányát. Az elemzés kitér a szakirányú továbbképzésre is, amely nagyságrendjét tekintve mintegy fele, harmada létszámot képvisel, mint a részidős felsőoktatás, ugyanakkor nagyjából ugyanakkora, mint a diplomával továbbtanulók száma (benne a mesterfokozat megszerzését célzó továbbtanulásokkal is). A szakirányú továbbképzés kétségtelenül a „királyi út” egyik ága, különösen a pedagógus és jogi végzettségűek, valamint bizonyos gazdaságtudományi - elsősorban üzleti - végzettségűek számára. A tanulmány befejezésül kitér annak elemzésére, hogy megéri-e a felnőttkori tanulás, illetve kinek mennyire éri meg.

Összességében a tanulmány megállapítja, hogy a 2010 óta regnáló konzervatív kormány visszafogó felsőoktatás-politikájának hatására a felsőoktatási felnőttképzésben nemcsak a pótlási út szükült be, hanem a királyi út is. Pedig a felnőttkori tanulás kifizetődő befektetés mind az egyénnek, mind a társadalomnak, amely előnyök indokolttá tennék a felnőttképzés kiemelt oktatáspolitikai kezelését.

Kulcsszavak: felsőoktatási felnőttképzés, szakirányú továbbképzés, felnőttkori tanulás megtérülése

The study deals with adult education in higher education, which has undergone significant change since the end of the 20th century: the former compensatory, complementary role was replaced by the continuing education and retraining role. For the first time, the study provides an overview of the student population of the last 25 years of Hungarian higher education and the recent enrollment trends, examining the age structure of enrolled students, the proportion of part-time students and those with a previous degree. The analysis also covers postgraduate specialisation programmes, which, in terms of size, represents about half and one-third the number of part-time tertiary education

Levelező szerző: Polónyi István, Debreceni Egyetem Bölcsészettudományi Kar, Nevelés- és Művelődéstudományi Intézet. E-mail: istvan.polonyi@arts.unideb.hu 
students, but roughly the same as the number of graduate students (including master's degree students). The postgraduate specialisation programmes is undoubtedly one of the 'royal paths', especially for educators and law graduates, as well as for some economics graduates, especially business graduates. The study concludes by analyzing whether and to what extent adult learning is worth it based on its internal rate of return.

Overall, the study concludes that as a result of the conservative government's reigning policy on higher education since 2010, not only the path to replacement but also the royal path has been narrowed in adult education. However, adult learning is a rewarding investment for both the individual and society, which would justify the priority treatment of adult education in education policy.

Keywords: adult education in higher education, postgraduate specialisation programmes, return on adult learning

\section{Bevezetés}

$\mathrm{E}$ bben a tanulmányban ${ }^{1}$ egy fontos tanulmányi úttal, a felsőoktatási felnőttképzéssel foglalkozunk. Itt felsőoktatási felnőttképzés alatt a 35 éves és idősebbek felsőoktatási részvételét, valamint (kortól függetlenül) a részidős felsőoktatási képzéseket értjük (kivéve a felsőfokú szakképzést, amely a hazai jogi szabályozás szerint nem ad felsőfokú végzettséget).

A felnőttképzés - benne a felsőoktatási felnőttképzés - jelentős változáson ment keresztül a 20. század végétől. A felnőttképzés szerepe korábban egyfajta kompenzálás, pótlás volt - nevezetesen az igazságtalan oktatási rendszerből gazdasági vagy társadalmi okok miatt kimaradtak számára lehetővé tenni a magasabb szintű végzettség megszerzését. "Jellegzetesen ilyen szerepe volt Európában még sokáig, különösen Európának azokon a térségein, abol totalitárius rendszerek jöttek létre a társadalmi igazságosság nevében (a második világháború elött a fasiszta, a második világháború után pedig a kommunista rendszerekben). Az Egyesült Államok esetében ilyen szerep jutott a felnöttképzésnek részben az 1930-as évek elején - Roosevelt New Deal-jéhez kapcsolódva - részben pedig az 1960-as években, Johnson Nagy Társadalom programja keretében" (Kozma 2000). Hozzáteszi, hogy ez a pótló szerep ma is megvan azokban a társadalmakban, ahol nagy a bevándorlás. „Ez a pótló, igazságtevő szerepe a felnöttképzésnek azonban látnivalóan eltörpült, visszaszorult mára. [...] A felnöttképzés e megváltozott szerepét éppen az jellemzi az 1990-es évek végén, hogy benne a felsőfokú végzettségüek aránya dominál. [...] A felnöttképzésben mindinkább az iskolázottabb társadalmi csoportok vesznek részt - az iskolázatlanabbak pedig egyre kevésbé. A felnöttképzés nem pótolja, helyettesiti az iskolázottság biányait, hanem folytatja és kiegésziti." (Kozma 2000.)

Tegyük hozzá, hogy a fejlett, gazdagabb országokban a felsőoktatásban a szakképzés mellett egyre nagyobb szerepet kapnak a „rekreációs” képzések, a „tanulva-szórakozás”, az oktatás fogyasztása. Egyértelmü, hogy a felsőoktatás ugyanolyan fogyasztási cikké kezd válni, mint az üdülés, az olvasás, vagy a szórakozás.

\footnotetext{
A tanulmány alapjául szolgáló kutatás a „Társadalmi és szervezeti tényezők szerepe a hallgatói lemorzsolódásban" című, 123847. számú, a Nemzeti Kutatási Fejlesztési és Innovációs Alapból biztosított projekt támogatással, a K17 pályázati program finanszírozásában valósult meg.
} 
Tehát, témánk megközelítésében, megváltoztak a felsőoktatási felnőttképzésben a tanulási utak, illetve azok rekrutációja.

\section{A hazai felsőoktatás elmúlt negyed századának hallgatólétszám-alakulása}

A hazai felsőoktatás az elmúlt negyed századában igen radikális átalakuláson ment át. A teljes részvételi hányad (Gross Enrolment Ratio) a rendszerváltást követő expanzió után 2007-ben érte el a maximumot, majd csökkenni kezdett, amely csökkenés 2011 után, a konzervatív kormánykoalíció hatalomra kerülése nyomán egészen radikálissá vált (1. ábra).

Ennek nyomán Magyarország 2016-ban az adatot közlő 35 OECD-tagország között a 33. helyre esett vissza, mögöttünk csak Szlovákia és Litvánia áll, az EU 28 tagországa ${ }^{3}$ között pedig 25. helyen voltunk (mindössze Szlovákiát, Romániát és Luxemburgot megelőzve).

Értelemszerűen a részvételi hányad a hallgatólétszám alakulásával hasonló lefutású, a csúcsot jelentő 2005-höz viszonyítva a 2017-es létszám harmadával kisebb (2. ábra). Az összes hallgatólétszámon belül a nappali tagozatos hallgatólétszám csökkenése annak 2008-as csúcsához viszonyítva 17\%-nyi, viszont a részidős képzésé a saját 2004-es csúcsához viszonyítva közel 59\%.

A részidős képzés hallgatólétszáma tehát az elmúlt valamivel több mint 10 év alatt kevesebb mint felére esett vissza.

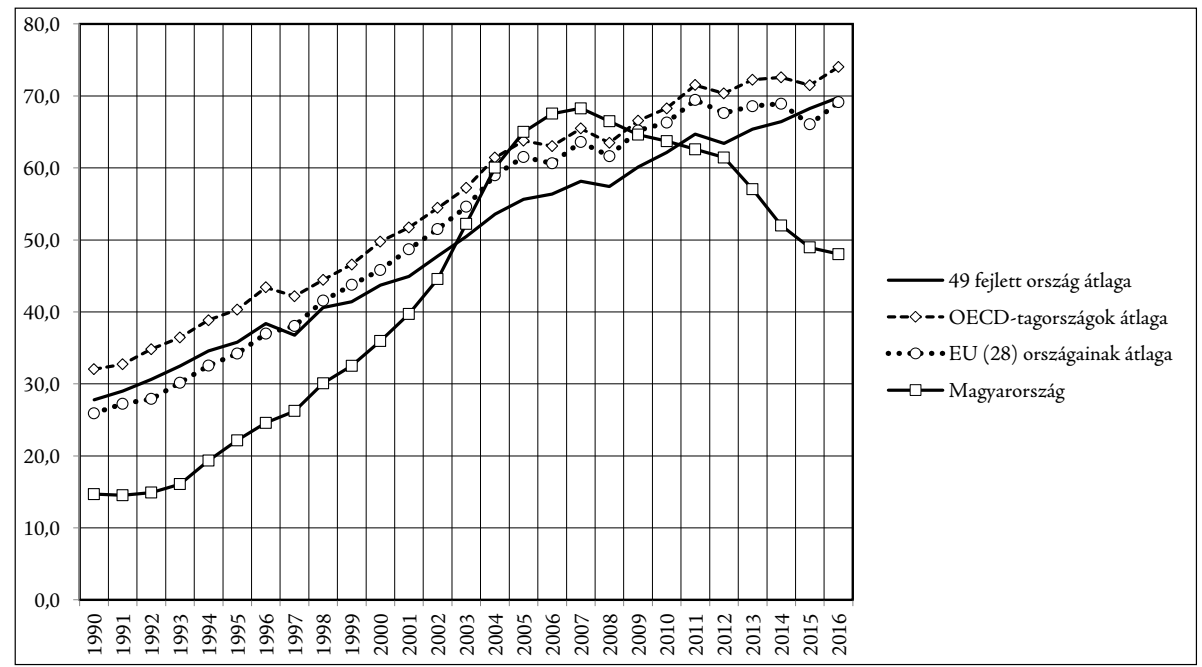

1. ábra: A felsőoktatás teljes részvételi hányadának alakulása Magyarországon és a nagy országcsoportokban. Forrás: UNESCO-adatbázis alapján saját számítás és szerkesztés

Az OECD-nek 2016-ban 35 tagországa volt (2018-tól van 36) - itt úgy tekintettük, mintha 1990 óta a 2016. évi 35 tagja lett volna.

3 Az EU tagországai esetében is úgy tekintettük, mintha a 2016. évi 28 tagország 1990 óta tag lett volna. 


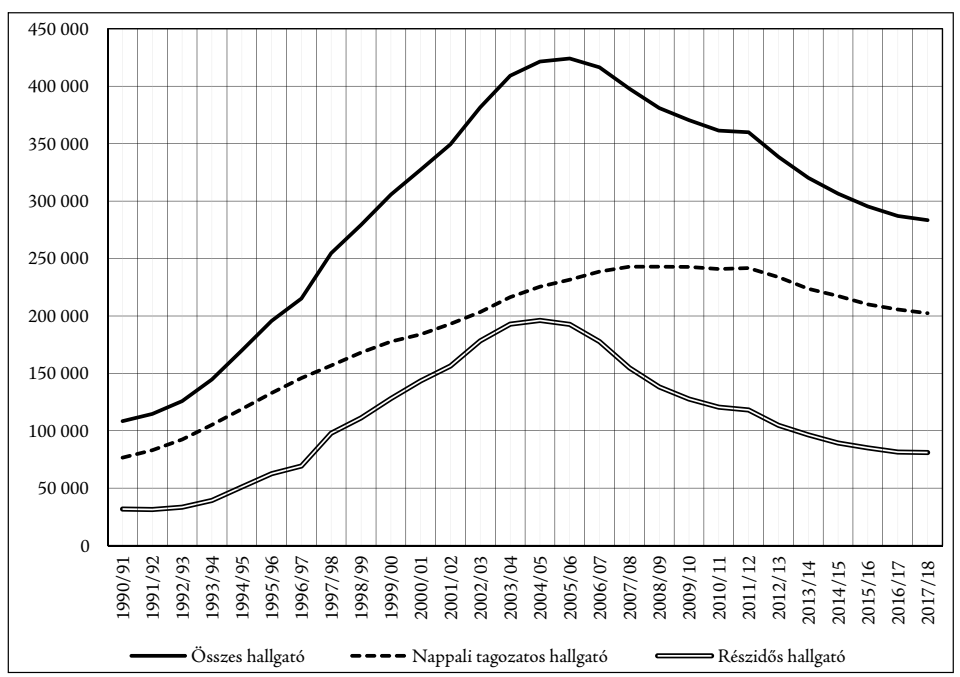

2. ábra: A felsőoktatási hallgatók munkarend szerinti létszámának alakulása Magyarországon (1990-2017). Forrás: Oktatási Hivatal felsőoktatási statisztika alapján saját szerkesztés

Érdemes legalább egy pillantás erejéig a létszámalakulást nemenként is megvizsgálni, mert ebben a tekintetben is radikális átalakulás történt. Mind a létszámokat és mind a teljes részvételi hányadot tekintve a csökkenés vesztesei a nők. Jóllehet megmaradt előnyük, azonban megfeleződött (Melléklet 1. és 2. ábra).

\section{A felvételi tendenciák}

A z évente felvett hallgatólétszám jól mutatja a részidős képzéssel kapcsolatos egyéni kereslet és az oktatáspolitika átalakulásait (3. ábra).

A részidős képzés iránti kereslet 2004 után kezdett el csökkenni, ami - a felsőoktatási felvételi rendszer sajátosságai miatt - a felvett létszámot is meghatározta, amely hasonlóan csökkenésnek indult. A részidős képzés iránti kereslet csökkenésének több okát azonosíthatjuk.

Az egyik meghatározó ok alighanem a felsőoktatás tömegesedése előtti halasztott továbbtanulási igények kiapadása.

A másik a 2006-ban az új felsőoktatási törvény életbelépésével és az új kormány belépését követően ismét megfogalmazódó tandíjelképzelések. Jóllehet ebből nem lett semmi, mivel 2008-ban - az ellenzék népszavazási kezdeményezése nyomán - a tandíjat elvetették a szavazók, így az nem került bevezetésre. Azonban már a tandíj híre is elegendő volt, hogy mind a nappali tagozat, mind a részidős képzés iránti keresletet radikálisan csökkenjen. Ezt a feltételezést támasztja alá a 2013. évben tapasztalható hasonló keresletcsökkenés is, ami a miniszterelnök önfenntartó felsőoktatásra és a hallgatók széles körű teherviselésére vonatkozó kijelentése és a költségtérítés önköltségi szintre emelése nyomán következett be.

A tandíj hírére és a költségtérítés emelésére történő keresletcsökkenés azt mutatja, hogy a felsőoktatás iránti kereslet igen erősen ár- (tandíj)függő, azaz valószínűleg igen 


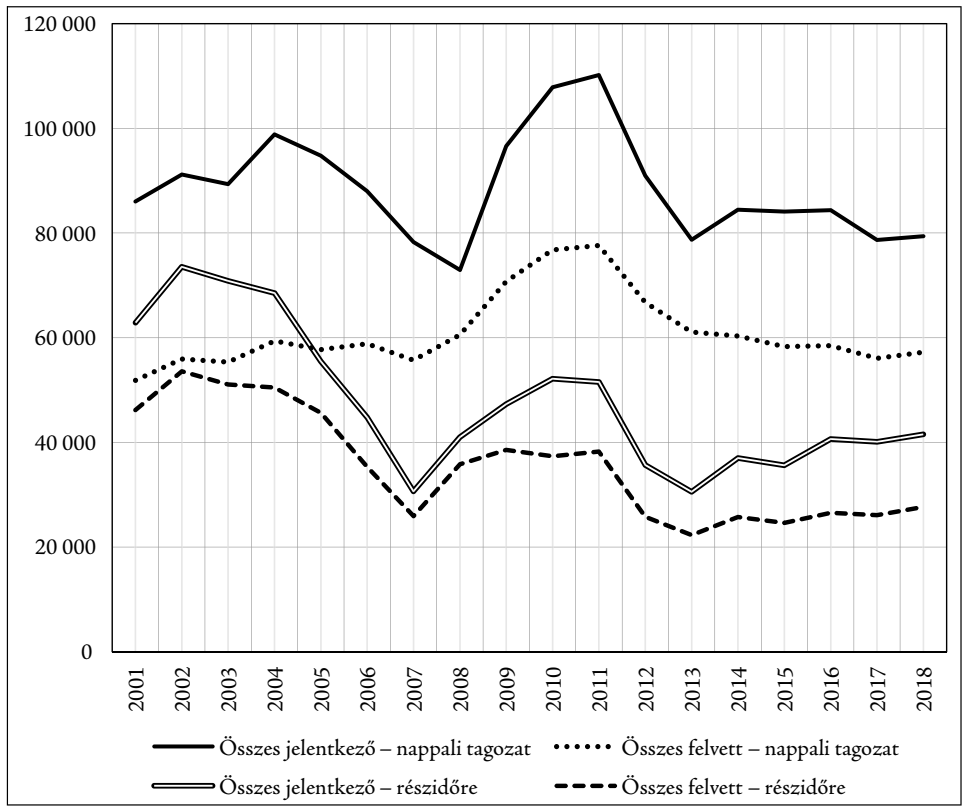

3. ábra: A jelentkezők és felvettek létszámának alakulása Magyarországon (2001-2017). Forrás: Felvi.hu adatai alapján saját szerkesztés

sok felsőoktatásban tanuló vagy oda törekvő az anyagi teherviselés határán van, sígy az anyagi terhek növekedése radikálisan hat a keresletre.

2013 után - a konzervatív kormány visszafogó oktatáspolitikája nyomán - végül is alacsony szinten stabilizálódott mind a nappali, mind a részidős képzés felvett létszáma.

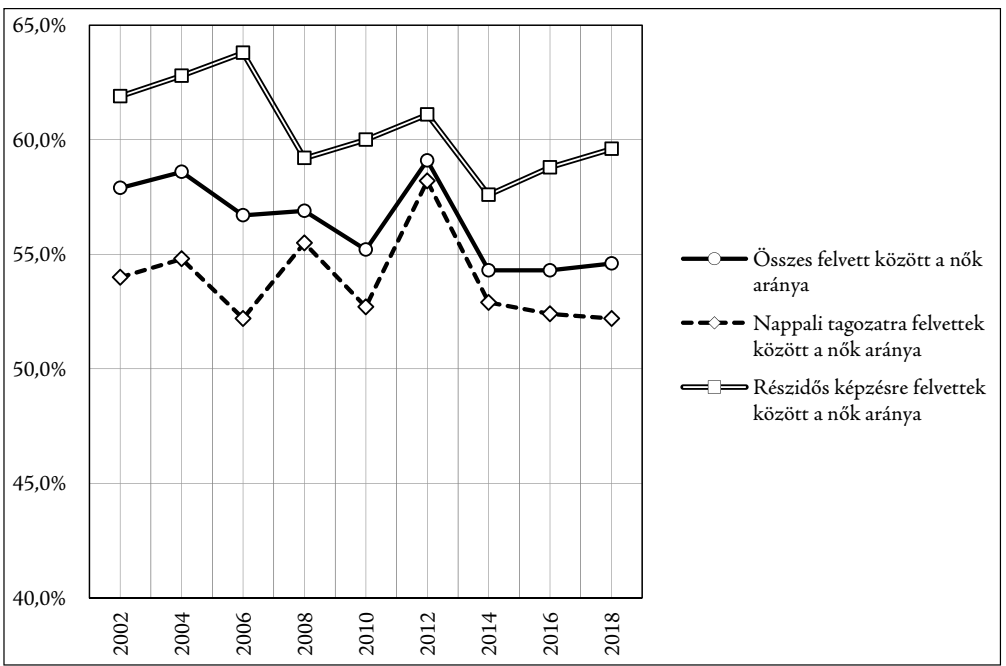

4. ábra: Az adott éven felvettek között a nők arányának alakulása Magyarországon.

Forrás: Adott évi felvételi adatbázis alapján saját számítás és szerkesztés 
Szembetűnő a nők arányának alakulása is a felvettek között. A 2000-es évek első évtizedének közepétől a részidős képzésre az adott évben felvettek között a nagyon magas nőarány az évtized végére csökkent (4. ábra).

Úgy tűnik - pl. a nőarány 2012-es megugrásából -, hogy a tandíjfenyegetés inkább a férfiakat riasztotta el, viszont az is látszik, hogy hosszú távon a nők aránya folyamatosan csökken, különösen 2014 óta. A tendencia alakulásában több tényező játszott szerepet. Az egyik nyilván az eltérő társadalmi rétegződés és az ebből adódó eltérő továbbtanulási motivációk, amiről viszonylag keveset tudunk. Egy további tényező az, hogy a nőkre vonatkozó kedvezmények lassan kikoptak a felsőoktatásból. ${ }^{4} \mathrm{~A}$ nők arányának csökkenésében ezeken kívül alapvető szerepet játszik az is, hogy az államilag támogatott képzési helyek jelentősen átrendeződtek a kormányzati beavatkozás nyomán a képzési területek között. Részint a nők által kedvelt, népszerü (bölcsész és társadalomtudományi) szakok bejutási pontszámának radikális megemelése, lényegében önköltségessé tétele nyomán, részint a nők által kevésbé keresett műszaki, informatikai, természettudományi szakok preferálása a részidős képzésben (is).

\section{A felvettek korstruktúrája}

A felsőoktatási felnőttképzés átalakulása - azaz a pótló szerep helyett a továbbképző szerep előtérbe kerülése - azzal igazolható, hogy az a felvettek között a diplomások arányának növekedésével jár. $\mathrm{A} z$ átalakulásnak az átlagéletkorra való hatása kevésbé azonosítható, hiszen mind a pótló, mind a továbbképző szerep növel(het)i az átlagéletkort.

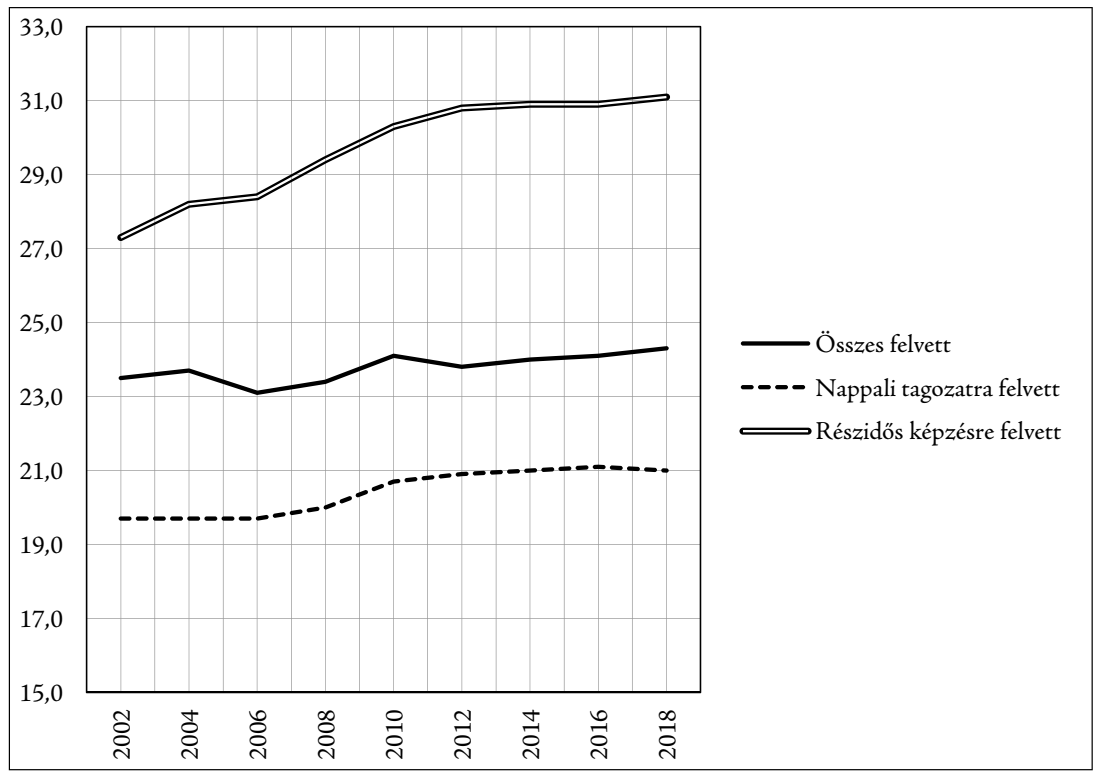

5. ábra: Az adott évben felvett hallgatók átlagéletkorának alakulása. Forrás: Adott évi felvételi adatbázis alapján saját számítás és szerkesztés

Például 2007-ben megszűnik a terhességi-gyermekágyi segélyben, gyermekgondozási segélyben, gyermeknevelési támogatásban vagy gyermekgondozási díjban részesülő hallgatók költségtérítésének elengedése. 


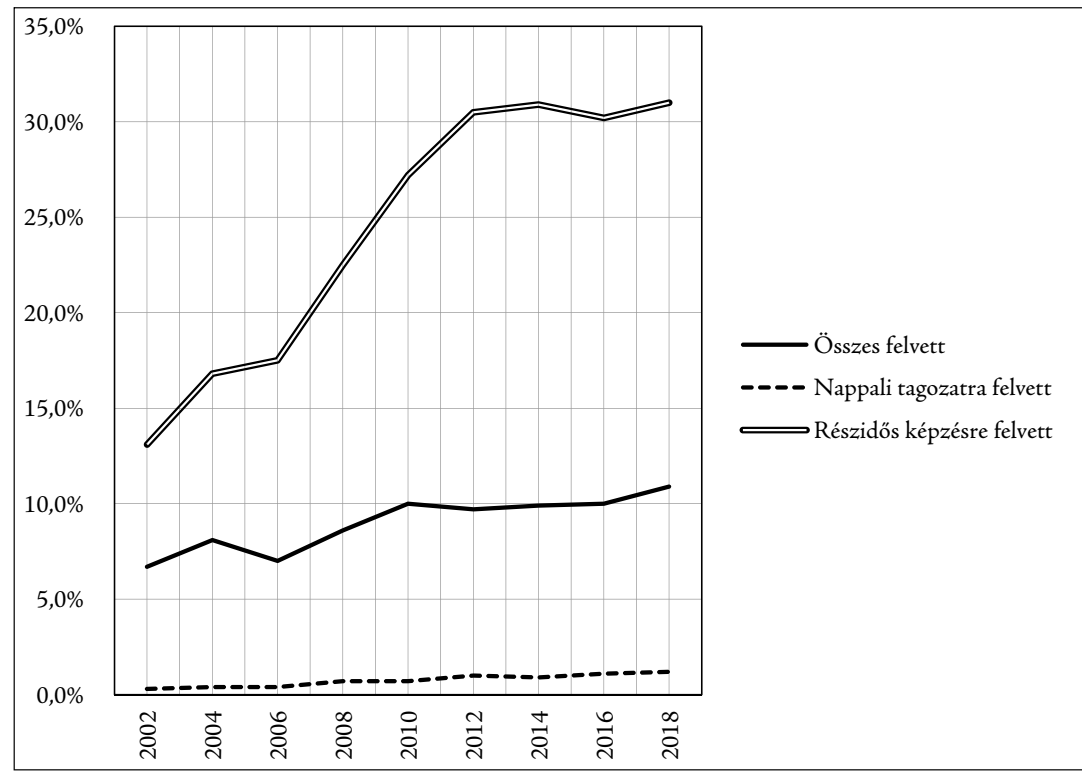

6. ábra: Az adott évben felvett hallgatók között a 35 évesek és idősebbek arányának alakulása.

Forrás: Adott évi felvételi adatbázis alapján saját számítás és szerkesztés

A felvett hallgatók átlagéletkorát vizsgálva egyértelműen látszik a részidős képzésre felvettek átlagéletkorának folyamatos növekedése, majd annak megtorpanása (5. ábra). Ha a 35 éves és idősebb hallgatók arányát vizsgáljuk a felvett hallgatók között (6. ábra),

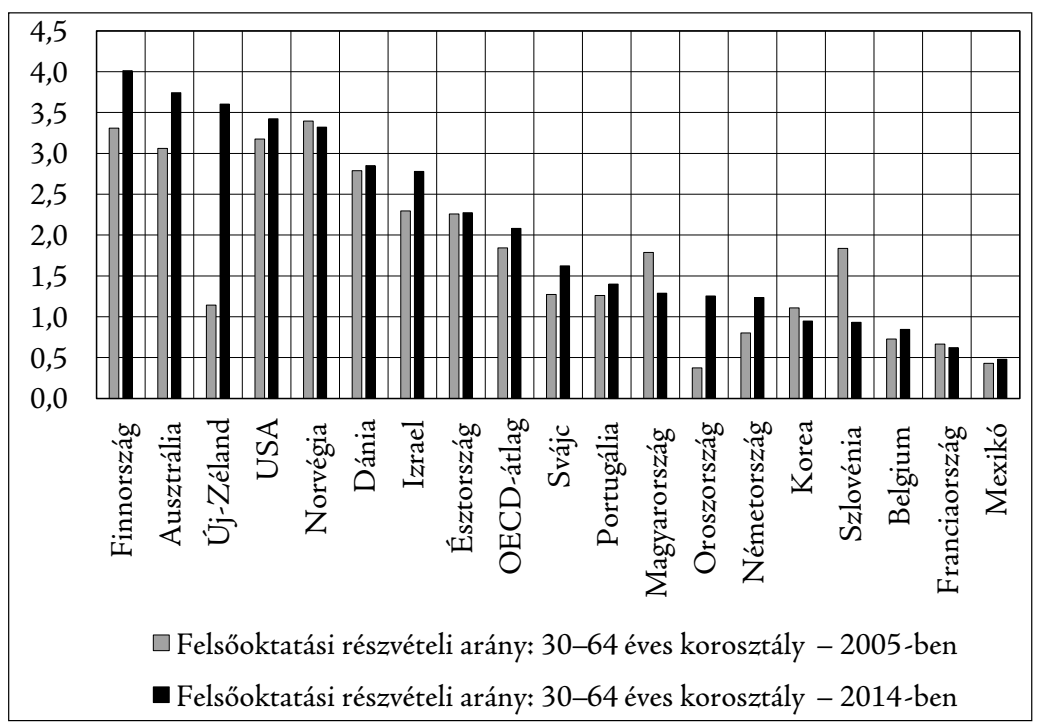

7. ábra: A 30-64 éves korosztály felsőoktatási részvételi aránya 2005-ben és 2014-ben az adatközlő OECD- (és partner)országokban. Forrás: OECD-adatbázis alapján saját számítás és szerkesztés 
jól látható, hogy az 2002 és 2012 között több mint kétszeresére (13,1\%-ról 30,5\%-ra) gyarapodott, azóta viszont stagnál.

Ami egyértelműen látszik: a részidős hallgatók esetében mind az átlagéletkor-, mind az idősebb hallgatók arányának növekedése 2012 óta megállt.

Nemzetközi összehasonlításban csak néhány olyan ország van, ahol a felvett hallgatók között a 30-64 éves korosztály részvételi hányada csökkent 2000 és 2014 között. Az egyik ilyen Magyarország - mellette Szlovénia még ilyen (és egészen kis mértékben Norvégia), ahol azonban ez az arány viszonylag magas (7. ábra).

A hazai adatok alapján a diplomások arányára tekintve az alap- és osztatlan képzésre felvettek között egyértelmúen látszik a diplomával már rendelkezők arányának csökkenése. Ugyanakkor a részidős képzés esetében a diplomások aránya együttmozog a felvettek létszámával (8. ábra), minél több a felvett részidős hallgató, annál nagyobb a diplomások aránya, ami nem mond annak ellent, hogy növekszik a részidős képzés továbbképző szerepe.

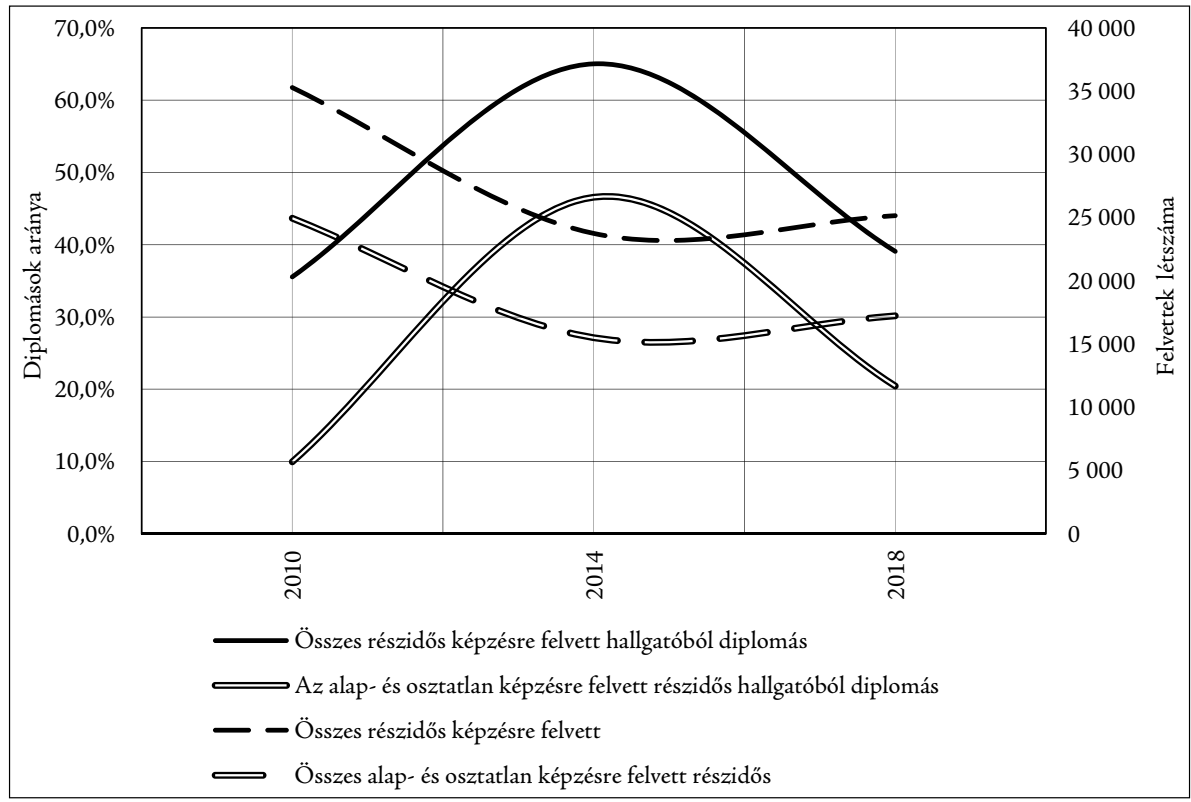

8. ábra: Az adott évben felvett hallgatók között a diplomások arányának alakulása. Forrás: Adott évi felvételi adatbázis alapján saját számítás és szerkesztés

A hazai adatok tehát csak részben látszanak igazolni a pótlás helyett továbbképzés tendenciát, azonban ennek az az oka, hogy nálunk 2010 óta egy a fejlett világgal ellentétes felsőoktatás-szükítés érvényesül, ami torzítja a folyamatokat. ${ }^{5} \mathrm{~A} z$ adatok arról tanúskodnak, hogy a 2010-es kormányváltás óta a konzervatív oktatáspolitika nyomán a felsőoktatási felnőttképzés beszűkülni látszik. A beszűkülés nemcsak az első diplomaszerzést

Azt is hozzá kell tenni, amit Garai (2014) állapított meg: a részidős munkarenden felsőoktatási tanulmányaikat folytató hallgatók nem képeznek homogén egységet. 
célzó felsőoktatási felnőttképzést érinti, hanem a diplomások újabb diplomaszerzésre irányuló törekvéseit is.

\section{A szakirányú továbbképzés}

A szakirányú továbbképzés ISCED 5A szinten történő képzés, amely újabb végzettséget nem ad. (Oktatás-statisztikai évkönyv 2010.)

„A szakirányú továbbképzések már megszerzett végzettségre és meghatározott szakképzettségre épülö, újabb végzettséget nem adó képzések, amelyek speciális szakirányú szakképzettséget tanúsító oklevél kiadásával zárulnak. [...] A jellemzően 4 féléves szakirányú továbbképzéseken nem tömeges a részvétel." (Farkas 2014.)

A szakirányú továbbképzésben részt vevők létszáma 2003 és 2012 között jelentősen csökkent, amit 2013-ban hirtelen létszámugrás követ (9. ábra).

A 2013-ban tapasztalható létszámkiugrás a "Tanárképzés, oktatástudomány” ISCED főirány (magyarul a pedagógusok szakirányú továbbképzései) területén megnövekedett létszámnak köszönhető. (2014-ben 3538 fö volt a „Tanárképzés, oktatástudomány" ISCED föirányban a szakirányú továbbképzésben végzettek száma, 2015ben közel 5 ezer, majd 2016-ban mintegy 4,5 ezer, 2017-ben pedig már ismét 4 ezer fö alatt volt.) A kiugrás alighanem a pedagógusok életpályamodelljének bevezetése nyomán megugrott pedagógus-továbbképzésben részt vevők száma miatt következett be (1. táblázat).

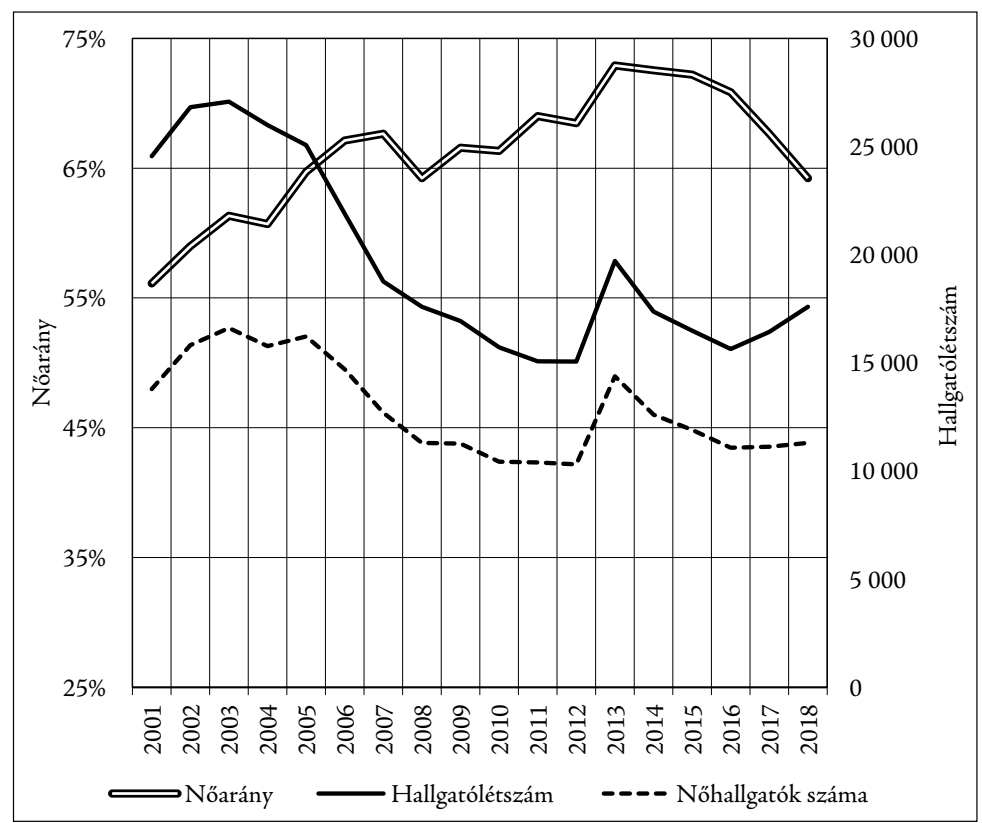

9. ábra: A szakirányú továbbképzés hallgatóinak száma és nemi megoszlása. Forrás: Oktatás-statisztikai évkövek és Oktatási Hivatal felsőoktatási statisztika alapján saját számítás és szerkesztés 
1. táblázat: A pedagógus-továbbképzésben részt vevők aránya a szakirányú továbbképzést végzettek között

\begin{tabular}{lrrrrr}
\hline A szakirányú továbbképzésben végzettek & $\begin{array}{c}2013 \\
(\%)\end{array}$ & $\begin{array}{c}2014 \\
(\%)\end{array}$ & $\begin{array}{c}2015 \\
(\%)\end{array}$ & $\begin{array}{c}2016 \\
(\%)\end{array}$ & $\begin{array}{c}2017 \\
(\%)\end{array}$ \\
\hline ISCED föirányok szerint & 31,0 & 42,9 & 52,2 & 48,9 & 46,2 \\
Oktatás & 53,9 & 36,8 & 30,0 & 29,7 & 33,1 \\
Múrsadalomtudománi, ipari és építőipari képzések & 3,6 & 6,2 & 5,0 & 6,6 & 6,6 \\
Humán tudományok és müvészetek & 3,2 & 4,6 & 4,6 & 5,9 & 5,6 \\
Szolgáltatások & 1,8 & 3,1 & 3,5 & 3,3 & 3,6 \\
Mezőgazdaság és állatorvosi tudományok & 1,1 & 3,2 & 3,2 & 2,6 & 3,4 \\
Egészségügy és szociális gondoskodás & 0,8 & 2,4 & 0,7 & 2,0 & 0,9 \\
Matematika, számítástechnika, egyéb termé- & 0,4 & 0,6 & 0,6 & 0,7 & 0,4 \\
szettudományok & 4,3 & 0,2 & 0,2 & 0,3 & 0,2 \\
Ismeretlen & & & &
\end{tabular}

Forrás: Oktatási Hivatal felsőoktatási statisztika alapján saját számítás

A szakirányú továbbképzésben végzettek ISCED főirányok szerinti megoszlása azontúl, hogy megerősíti a fentebb mondottakat, arra is rávilágít, hogy a szakirányú továbbképzésben meghatározott szakmák továbbképzése dominál. A pedagógusok, a jogi és az üzleti tudományok irányú képzés teszi ki a képzés résztvevőinek több mint $70 \%$-át.

A végzettek számát tekintve azok legnagyobb hányadát a pedagógusok továbbképzése teszi ki (2013-ban közel 3,5 ezer, 2017-ben 4 ezer fó volt). Ezt követi az üzleti és ügyviteli szakirány, ami 2013-ban meghaladta az oktatásit (több mint 4,5 ezer fó volt), de 2015-ben 1200-ra, 2016-ban pedig 1100-ra esett. A harmadik legnépesebb szakirány

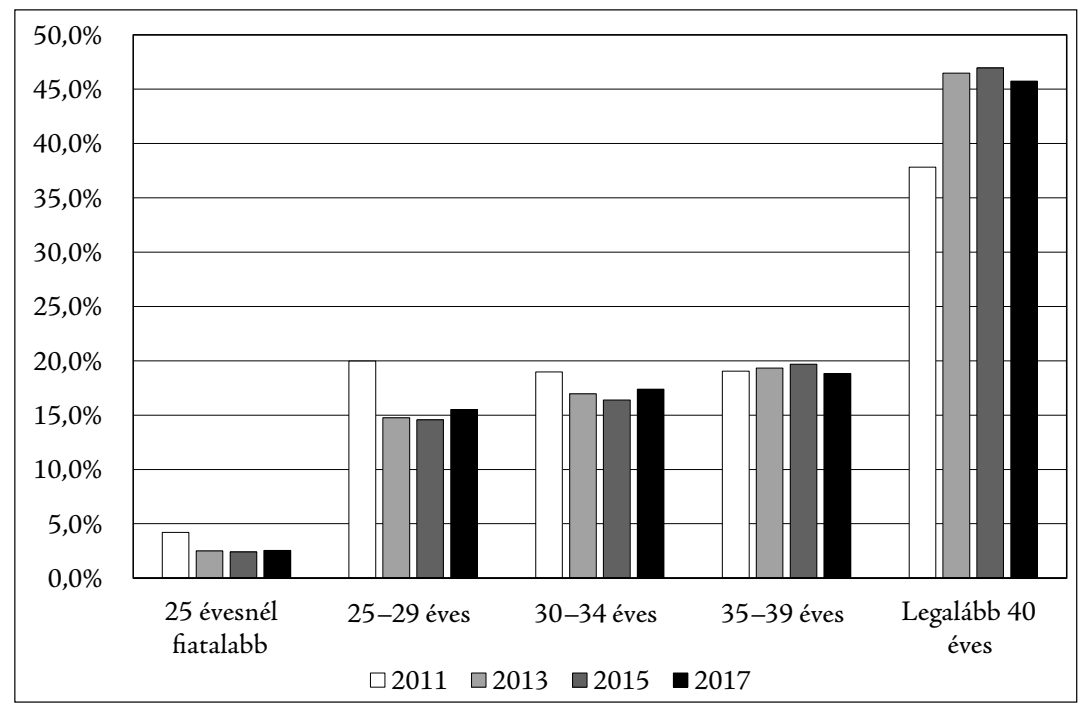

10. ábra: A szakirányú továbbképzésben tanulók életkor szerinti megoszlása (2011-2017).

Forrás: Oktatási Hivatal felsőoktatási statisztika alapján saját számítás és szerkesztés 
a jogi továbbképzés, amelyen az utóbbi öt évben 650 és 850 között mozgott a végzettek száma.

A szakirányú továbbképzésben tanulók átlagéletkora 37 és 38 év között van. Legnagyobb részük 40 éves vagy annál idősebb. 2013 óta több mint $45 \%$ ebbe a korcsoportba tartozik (2011-ben csak 38\%). 2013-ban, amikor megugrott az összes szakirányú hallgató létszáma, akkor éppen ezen idősebb korosztályba tartozók száma növekedett (2011-ről 2013-ra majdnem 10\%-kal) (10. ábra).

A szakirányú továbbképzés nagyságrendjét tekintve mintegy fele, harmada létszámot képvisel, mint a részidős felsőoktatás, ugyanakkor nagyjából ugyanakkora, mint a diplomával továbbtanulók száma (benne a mesterfokozat megszerzését célzó továbbtanulásokkal is). A szakirányú továbbképzés kétségtelenül a „királyi út” egyik ága, különösen a pedagógus és jogi végzettségűek, valamint bizonyos gazdaságtudományi - elsősorban üzleti - végzettségűek számára. A szakirányú továbbképzést is érintette a tömegesedés utáni megtorpanás, de a 2010 -es radikális oktatáspolitikai váltás hatása itt máshogyan érvényesül. A csökkenés helyett a pedagóguséletpálya-modell bevezetése nyomán megélénkülő továbbképzés iránti kereslet növelő hatása látszik. Ezzel együtt a szakirányú továbbképzés iránti kereslet struktúrájában is változás következett be: a pedagógus-továbbképzés kiterjedése és az üzleti tudományok visszaszorulása tapasztalható.

\section{Megéri-e a felnőttkori tanulás?}

A felnőttképzési tanulmányi út vizsgálatánál célszerü kitérni arra is, hogy megéri-e a felnőttkori tanulás, illetve kinek mennyire éri meg.

$\mathrm{A} z$ emberi tőke elmélete szerint - amelynek legismertebb teoretikusa Theodore W. Schultz - a munkaerő gazdasági szerepében meghatározó jelentőségű emberi tudás egy hosszú, költséges folyamat eredményeképpen alakul ki, amely leginkább a beruházási folyamathoz hasonlít, s a fogyasztásnak nevezett folyamat nem kis része az emberi tőkébe való beruházást jelent (Schultz 1983: 48). A teória szerint az emberi tőkébe történő ilyen beruházások megmagyarázzák az egy dolgozóra jutó reáljövedelem növekedésének legnagyobb részét. Az emberi képességeket növelő tevékenységeknek öt fő kategóriája van Schultz szerint: 1) az egészségügyi létesítmények és szolgáltatások, amelyek az emberek élettartamát, erejét, állóképességét, vitalitását és életképességét befolyásolják; 2) a munka közbeni képzés; 3) a formális, szervezett, elemi, közép- és felsőfokú oktatás; 4) a felnőttképzési programok; valamint 5) az egyének és családok vándorlása a változó munkalehetőségekhez való alkalmazkodás érdekében (Schultz 1983: 60).

Tehát a felnőttképzés termelékenységnövelő s bérnövelő szerepe a mainstream közgazdaságtan alapvető elmélete, mint ahogy az oktatás externális hatásai is (McMahon 2000), amelyek a társadalmi hasznokkal függenek össze. Ugyanakkor a felnőttképzés megtérülési rátájának nagyságáról az irodalomban elég eltérő vélemények vannak. Egyes irodalmak szerint (Heckman-Masterov 2007; Heckman 2011) a felnőttkori tanulás megtérülése alacsonyabb, mint az iskoláskori tanulásé. (Lásd 11. ábra.)

Más szakértői anyagok azonban ennél lényegesen magasabbra értékelik a felnőttkori tanulást.

Az Európai Bizottságnak készített, a „Felnőttkori tanulás finanszírozásáról” szóló 2013-as zárójelentés egyik kérdése, amelyre választ keres, hogy „Miért fektessünk a felnőttoktatásba”? A választ azzal kezdi az anyag, hogy „az előrejelzések azt mutatják, hogy 


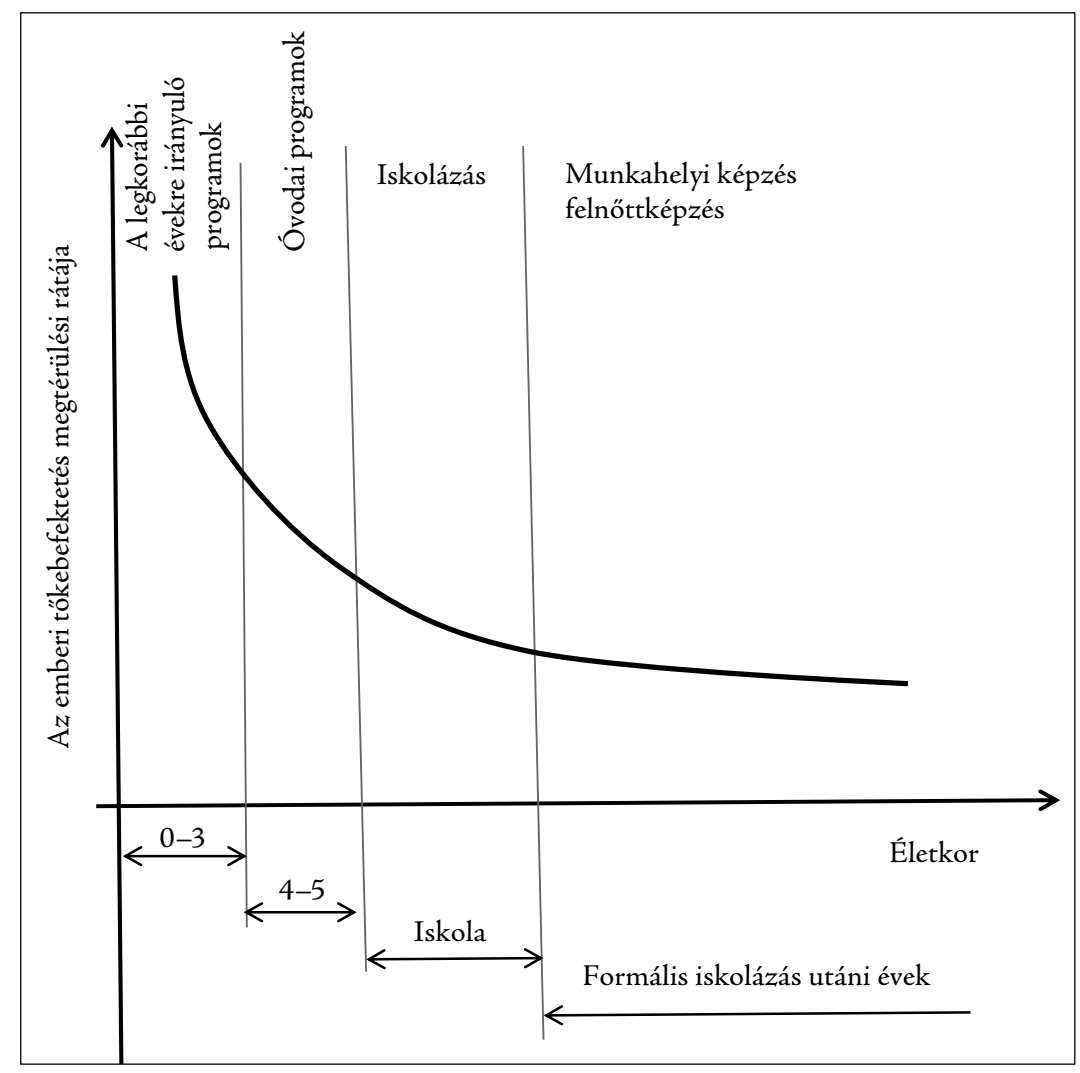

11. ábra: Az oktatási befektetések összegzése. Forrás: Heckman 2011: 82, 3. ábra alapján saját szerkesztés

2020-ra az összes munkahely több mint egyharmada felsőfokú képesítéseket igényel, és csak 15\%-a várhatóan alacsony képzettségű. Ugyanakkor jelenleg a felnőttek 25\%-a csak alacsony képzettségi szinttel rendelkezik. Ezért a felnőttkori tanulás is hozzájárulhat ahhoz a kiemelt célhoz, hogy [az EU-ban] 20 millió embert emeljen ki a szegénységből és a társadalmi kirekesztésből. A felnőttek képzettségi szintjének javítása javítja a foglalkoztatáshoz való hozzáférést.” Majd azzal folytatja, hogy „a tanulásban való részvétel pozitív hatással van a szélesebb társadalmi előnyökre is, mint például az egészségesebb életmód, a közösségi feszültség csökkenése és a jólét megtapasztalása. [...] Ugyanakkor szükség van a befektetések megtérülési rátájára vonatkozó jobb tájékoztatásra." (Financing Adult Learning 2013: 4.)

$\mathrm{A} z$ anyag hangsúlyozza, hogy a felnőttkori tanulás előnyei és költségei bizonyos helyzetekben egyszerüen kiszámíthatók, de a közpolitikai területeken sok olyan eset van, ahol a költségek és előnyök kevésbé kézzelfoghatóak és nehezebben számszerűsíthetők pénzben. Ehhez kapcsolódóan bemutatja a Financing Adult Learning 2013 tanulmányhoz készült angol szakértői anyag táblázatát a tanulás hasznairól, szélesebb körű előnyeiről (2. táblázat). 
2. táblázat: A tanulás szélesebb körü előnyei

\begin{tabular}{lll}
\hline & Magán & Közösség \\
\hline Pénzügyi & Növekvő jövedelem és gazdagság & Az adóbevételek növekedése \\
& $\begin{array}{c}\text { Növelt termelékenység } \\
\text { és jövedelmezőség }\end{array}$ & $\begin{array}{l}\text { Megnövekedett foglalkoztatás } \\
\text { Csökkentett egészségügyi költségek } \\
\text { Csökkentett bünözés }\end{array}$ \\
& & Társadalmi tőke \\
\hline \multirow{2}{*}{ Nem pénzügyi } & Jobb egészségügyi állapot & A társadalmi kohézió \\
& Nagyobb életviteli elégedettség & Szociális bizalom \\
& Az egyéni jólét növelése & Jól müködő demokrácia \\
& & Politikai stabilitás \\
& & A gyermekszegénység csökkenése \\
\hline
\end{tabular}

Forrás: Financing Adult Learning 2013: 20

A fentiekhez hozzátartozik, hogy a felnőttképzés megtérülésével foglalkozó tanulmányok nagyobbik része alapvetően a munkahelyi képzésekre, illetve az alacsony iskolázottságúak felnőttképzési részvételére koncentrál s állapít meg jelentős megtérülést. Például Hanushek és szerzőtársai 23 országra kiterjedő elemzése azt igazolta, hogy a számolási készségek egy standard szintjének elérést célzó képzések az idősebb munkavállalók körében 18\%-kal növelték a bért (Hanushek et al. 2013). De pl. az UNESCO 2009. évi tanulmánya (UNESCO 2009) is az alacsony iskolázottságúak képzésének magas megtérülését emeli ki elsősorban.

Azonban több elemzés is szélesebb megközelítésben vizsgálja kérdést. A London School of Economics tanulmánya például megállapítja, hogy az egész életen át tartó tanulás bármely formájához való visszatérés elemzése azt sugallja, hogy a férfiak és a nők szempontjából jelentős pozitív hozamok vannak. A hatás nagysága mindkét nem esetében hasonló: a végzettség megszerzése után 10 évvel az óránkénti jövedelmek $20 \%-k a l$ növekedtek (Blanden et al. 2009). Az Egyesült Királyságra kiterjedő közelmúltbeli elemzés szerint a 30 évesnél idősebbek felsőfokú üzleti, valamint müszaki jellegű képzésének becsült megtérülési rátája - jóllehet alacsonyabb, mint a fiatalabbaké, de pozitív - 4-6\% körül van (Bhutoria 2016).

Jelen sorok írója is végzett számításokat az iskolarendszerű felnőttképzés megtérülését vizsgálva, és a felnövekvő nemzedék oktatási megtérülési rátáinál magasabb megtérülést mutatott ki (államilag finanszírozott képzés esetében, elhanyagolt lemorzsolódással). (Polónyi 2004.) Ez tulajdonképpen logikusnak is tűnik, hiszen a felnőttképzés esetében a kieső kereset - amely a ráfordítás egyik legnagyobb tétele - jelentősen kisebb, hiszen a felnőttképzési programok általában lényegesen intenzívebbek. Ugyanakkor a magasabb lemorzsolódás és a magasabb tandíj sokat ront a megtérülésen. Nyilván ebből adódik, hogy egy walesi elemzés azt állapítja meg, hogy ha az idősebb munkavállalók magasabb szintü képesítést szereznek - például a felsőoktatásban -, a megtérülés alacsonyabb, mint a fiatalabb munkavállalók esetében, azért, mert az oktatásban való részvételük alternatív költségei általában magasabbak, és megnövekedett jövedelmük kevésbé biztos (Connolly et al. 2008).

A viták ellenére leszögezhetjük, hogy a felsőoktatási felnőttképzés - bár vélhetőleg alacsonyabb, mint a fiatal nemzedéké, de - rentábilis befektetés. Más oldalról azt is hozzá 
kell tenni, hogy a felnőttkori tanulás megtérülése rendkívül differenciált, nyilvánvalóan más a fitalabb munkavállalók és a nyugdíjhoz közel állók esetében, és alighanem regionálisan is.

\section{Befejezésül}

A tanulmány elemzései arra mutatnak rá, hogy a felsőoktatási felnőttképzés átalakuláson ment/megy keresztül, amelynek lényege, hogy a vigaszági - azaz az elmaradt tanulmányok pótlására irányuló, első diplomaszerzésre irányuló - felnőttkori tanulás helyébe a királyi út folytatása, azaz a diplomára való rátanulás, új diplomaszerzés lép. Ebből adódóan növekszik a felsőoktatási felnőttképzésben tanulók átlagéletkora, s az ott tanuló idősebb hallgatók aránya.

A hazai tendenciák néhány tekintetben eltérnek a fentiektől, mégpedig annyiban, hogy a 2010 óta regnáló konzervatív kormány visszafogó felsőoktatás-politikájának hatására a felsőoktatási felnőttképzésben nemcsak a pótlási út szükült be, hanem a királyi út is, azaz nemcsak az első diplomaszerzésre törekvő felnőttek száma csökken, hanem a diplomások továbbtanulása is megtorpant.

Elég egyértelműen látszik, hogy a hazai oktatáspolitika elfordult a fejlett világ törekvéseitől, ami a felnőttképzésben is megtorpanást hozott.

\section{IRODALOM}

Bhutoria, A. (2016) Economic Returns to Education in the United Kingdom. Foresight Government Office for Science. https://assets.publishing.service.gov.uk/government/ uploads/system/uploads/attachment_data/file/593895/Economic_Returns_To_ Education_-_final.pdf [Letöltve: 2019. 08. 21.]

Blanden, J., Buscha, F., Sturgis, P. \& Urwin, P. (2010) Measuring the Returns to Lifelong Learning. London, Centre for the Economics of Education, London School of Economics.

Connolly, M., Rees, G. \& Furlong, C. (2008) Research E Development Informing Policy and Practice in Adult Learning. The Wider Benefits of Adult Learning NIACE. http:// www.assembly.wales/NAfW\%20Documents/fin_3_-fhe-05_-_niace_the_national_ institute_of_adult_continuing_education__dysgu_cymru_-_annex.pdf\%20-\%20 28012010/fin_3_-fhe-05_-_niace__the_national_institute_of_adult_continuing education__dysgu_cymru_-_annex-English.pdf [Letöltve: 2019. 08. 21.]

Farkas É. (2014) Felnőttképzés a felsőoktatásban. Educatio, Vol. 23. No. 2. pp. 253-269.

Financing Adult Learning (2013) Final Report. Thematic Working Group. Brussels, 22nd, October, 2013. https://www.hm.ee/sites/default/files/thematic_wg_financing_report. pdf [Letöltve: 2015. 12. 15.]

Garai O. (2014) Felnőttoktatás-e a részidős képzés? In: Kiss L. (ed.) A felsőoktatás szociális dimenziója. A Eurostudent V. magyarországi eredményei. Budapest, Educatio Társadalmi Szolgáltató Nonprofit Kft. pp. 67-78. https://www.felvi.hu/pub_bin/dload/ eurostudent/eurostudent_tanulmany_hu_VEGLEGES_web.pdf [Letöltve: 2017. 01. 21.]

Hanushek, E. A., Schwerdt, G., Wiederhold, S. \& Woessmann, L. (2013) Returns to Skills around the World: Evidence from PIAAC Working Paper Bureau of Economic Research. https://www.nber.org/papers/w19762.pdf [Letöltve: 2019. 08. 15.] 
Heckman, J. J. (2011) The American Family in Black \& White: A Post-Racial Strategy for Improving Skills to Promote Equality. Dedalus, the Journal of the American Academy of Arts E Sciences, Vol. 140. No. 2. pp. 70-89. http://jenni.uchicago.edu/papers/ Heckman_2011_Daedalus_v140_n2.pdf [Letöltve: 2017.01.21.]

Heckman, J. J. \& Masterov, D. V. (2007) The Productivity Argument for Investing in Young Children. Review of Agricultural Economics, Vol. 29. No. 3. pp. 446-493. http:// jenni.uchicago.edu/papers/Heckman_Masterov_RAE_2007_v29_n3.pdf [Letöltve: 2017. 01. 21.]

Kozma T. (2000) Negyedik fokozat? Info-Társadalomtudomány, No. 49. (október) pp. 61-74.

McMaron, W. W. (2000) The Measurement of Externalities, Non-Market Effects, and Trends in the Returnsto Education. In: The Appraisal of Investments in Educational Facilitries. European Investment Bank/OECD. Paris, OECD.

Polónyi I. (2004): A felnőttképzés megtérülési mutatói. Budapest, Felsőoktatási Kutatóintézet.

Schultz, TH. W. (1983) Berubázások az emberi tőkébe. Budapest, Közgazdasági és Jogi Kiadó.

Schultz, TH. W. (1993) The Economic Importance of Human Capital in Modernization. Education Economics, Vol. 1. No. 1. pp. 13-19.

Szemerszki M. (2010) Frissdiplomások továbbképzése és továbbképzési stratégiái. In: Garai O., Horváth T., Kiss L., Szép L. \& Veroszta Zs: Diplomás pályakövetés IV: Frissdiplomások 2010. Budapest, Educatio Kht. pp. 83-104.

\section{MELLÉKLET}

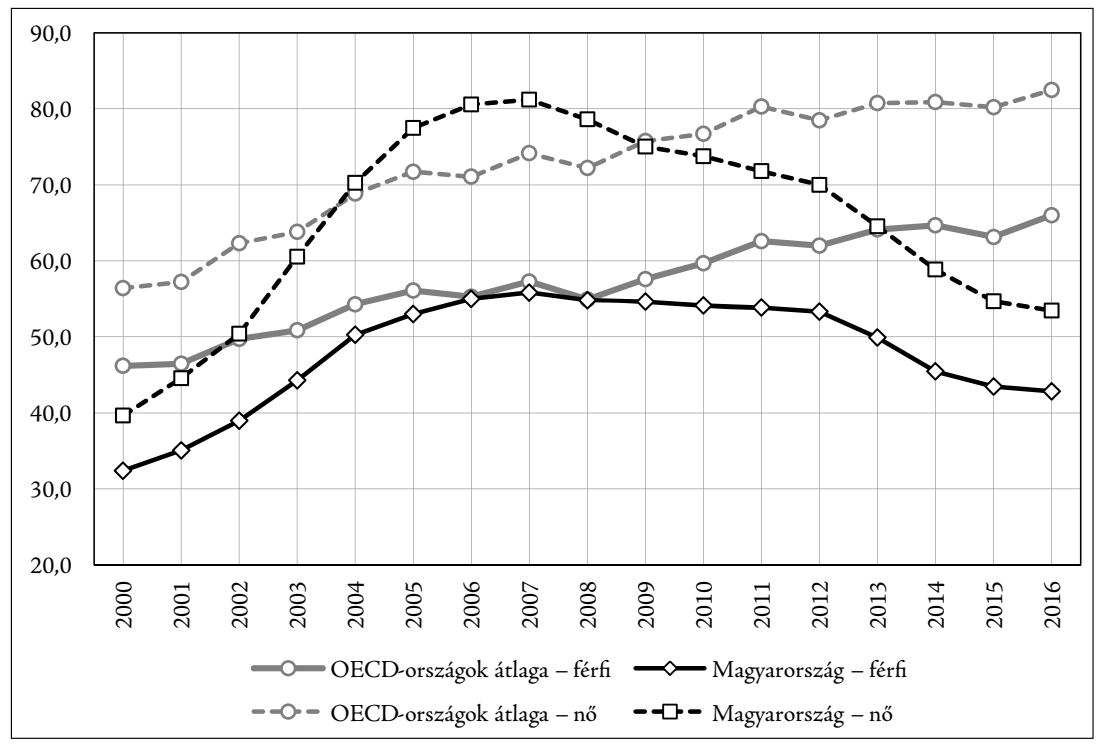

1. ábra: A felsőoktatás teljes részvételi hányadának alakulása nemenként Magyarországon és az OECD-országátlag. Forrás: UNESCO adatbázis alapján saját számítás és szerkesztés 


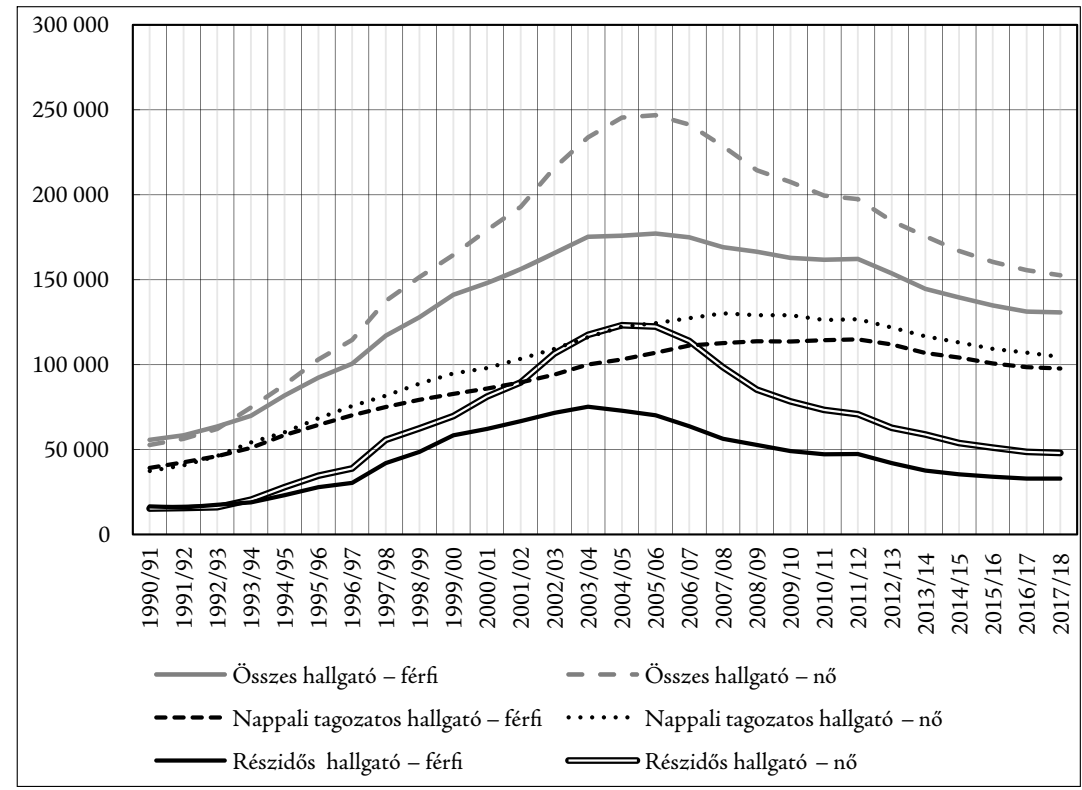

2. ábra: A felsőoktatás hallgatólétszámának alakulása nemenként és tagozatonként Magyarországon. Forrás: Oktatási Hivatal felsőoktatási statisztikák alapján saját számítás és szerkesztés

A cikk a Creative Commons Attribution 4.0 International License (https://creativecommons.org/licenses/ by/4.0/) feltételei szerint publikált Open Access közlemény, melynek szellemében a cikk bármilyen médiumban szabadon felhasználható, megosztható és újraközölhető, feltéve, hogy az eredeti szerző és a közlés helye, illetve a CC License linkje és az esetlegesen végrehajtott módosítások feltüntetésre kerülnek. (SID_1) 